\title{
Effect of ligamenta flava hypertrophy on lumbar disc herniation with contralateral symptoms and signs: a clinical and morphometric study
}

Hamit Selim Karabekir ${ }^{1}$, Ahmet Yıldızhan², Elmas K. Atar ${ }^{3}$, Soner Yaycıoglu4, Nuket Gocmen-Mas ${ }^{5}$, Canan Yazici ${ }^{6}$

1Department of Neurosurgery, Kocatepe University School of Medicine, Afyonkarahisar, Turkey

2Department of Neurosurgery, Yeditepe University School of Medicine, Istanbul, Turkey ${ }^{3}$ Neurosurgery, Spine Centre, Istanbul, Turkey

${ }^{4}$ Department of Neurosurgery, Adnan Menderes University School of Medicine, Aydın, Turkey

${ }^{5}$ Department of Anatomy, Kocatepe University School of Medicine, Afyonkarahisar, Turkey ${ }^{6}$ Department of Biostatistics, Baskent University School of Medicine, Ankara, Turkey

Submitted: 17 December 2009

Accepted: 8 March 2010

Arch Med Sci 2010; 6, 4: 617-622

DOI: 10.5114 /aoms.2010.14477

Copyright () 2010 Termedia \& Banach

\section{Abstract}

Introduction: The purpose of this study was to determine whether ligamentum flavum hypertrophy among disc herniated patients causes contralateral pain symptoms. For this reason we measured the thickness of the ligament in disc herniated patients with ipsilateral or contralateral symptoms.

Material and methods: Two hundred disc herniated patients with ipsilateral symptoms as group I were compared with five disc herniated patients with only contralateral symptoms as group II. Ligamenta flava thicknesses and spinal canal diameters of both groups were measured on magnetic resonance imaging (MRI) with a micro-caliper.

Results: Both groups underwent surgery only on the disc herniated side. The total thicknesses of the ligamenta flava in group II was thicker than in group I. There was no spinal stenosis in either group and no significance difference between the groups. Statistically significant differences were found for both ipsilateral and contralateral thickness of the ligament flava in both groups. We also compared thickness of the ligamenta flava for each level of disc herniation in group I; ligamenta flava hypertrophy was more common at L3-L4 and L4-L5 levels of vertebrae in females.

Conclusions: Aetiology of contralateral sciatica among disc herniated patients may be related to hypertrophy of the ligamenta flava, especially on the opposite side. Surgical approaches of the disc herniated side alone may be sufficient for a good outcome.

Key words: contralateral symptoms, ligamentum flavum hypertrophy, lumbar disc herniation, morphometry, magnetic resonance imaging.

\section{Introduction}

The vertebral column is remarkable as it combines mobility, stability and load-bearing capacity and also protects contained neural structures such as spinal nerves, irrespective of its position [1]. Regional variations in mobility of the spine depend on the geometry, orientation and properties

\section{Correspondence address:} Hamit Selim Karabekir, MD Kocatepe University Faculty of Medicine Department of Neurosurgery Afyonkarahisar, Turkey Phone: +90 27224633 20/3610 Fax: +902722463322 E-mail: hskarabekir@hotmail.com, hskarabekir@yahoo.com 
of both facet joints and related ligamentous complexes. The posterior longitudinal ligament, ligamenta flava, interspinous and supraspinous ligaments and posterior fibres of intervertebral discs are tensed, interlaminar intervals widen, inferior articular processes glide on superior processes of subjacent vertebrae and their capsules become taut. The ligamentum flavum has such a high content of elastin that it is always under tension, and can be stretched by $80 \%$ without damage. This ligament probably functions to provide a constant smooth lining to the vertebral canal, one of which is never overstretched in flexion and never goes slack in extension [1].

The intervertebral discs are the principal sites of vertebral column motion. In most levels they are the limiting factor for movement, especially pathologies such as disc herniations [1]. Herniation or protrusion of the nucleus pulposus into or through the annulus fibrosus is a well-recognised cause of low back pain [2]. The clinical symptoms seen in association with lumbar disc herniation may be based on pathophysiological involvement of spinal nerve roots or may be caused by ligament hypertrophy [3]. Chronic pain resulting from compression of the spinal nerve roots by the herniated disc is related to the dermatome supplied by that nerve [2]. All symptoms and signs are seen frequently on the same side as herniation but in rare cases contralateral side symptoms occur, which leads to the fact that surgeons are in doubt about the decision to perform disc surgery. Because surgeons are afraid of performing the operation on the wrong side and level [4], they prefer to delay the operation, which patients really need for satisfaction. In the current study we present five cases with lumbar disc herniation, all having contralateral signs and symptoms. They were operated on only from the herniation side and the outcome was sufficient. We discuss the possible

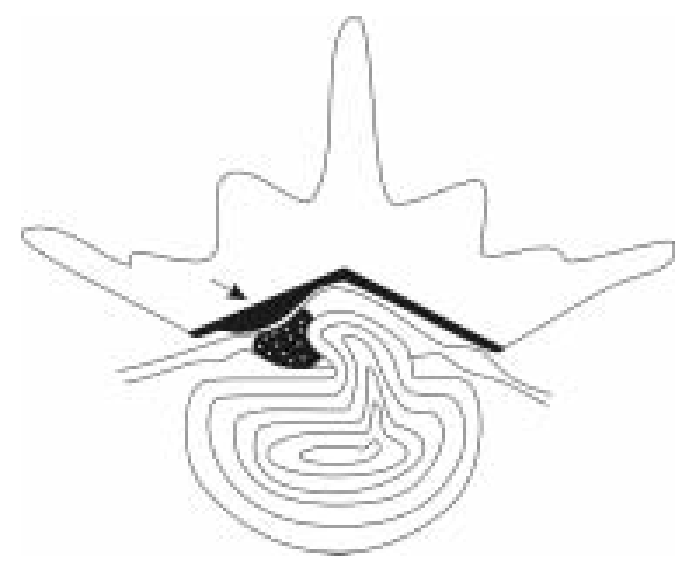

Figure 1. Herniated disc and asymmetrical hypertrophied ligamentum flavum (black arrow) are illustrated in the schematic drawing mechanism of the contralateral symptoms of these cases. We checked whether all of these five cases had asymmetrical and hypertrophied ligamentum flavum (Figure 1). We also discuss that the herniated disc caused displacement of the dural sac against the hypertrophied ligamentum flavum of the opposite side, resulting in contralateral radiculopathy, which seems in the pathomechanism of Kernohan's notch syndrome [5]. Thus, we aimed to find out the clinical and anatomical significance of the ligamentum flavum in patients with disc herniation by measuring on magnetic resonance imaging - (MRI) the thicknesses of the ligaments of 205 patients who had undergone surgery in group I and II.

\section{Material and methods}

\section{Clinical analysis}

Two hundred patients as group I, randomly selected among 4170 patients who had undergone surgery for lumbar disc herniation with ipsilateral signs and symptoms lasting for 15 years, were evaluated, retrospectively. This group consisted of 140 women (mean age $51 \pm 13$ years, range $22-81$ years) and 60 men (mean age $48 \pm 13$ years, range 19-73 years). During the same period, five consecutive patients who had undergone surgery for lumbar disc herniation with symptoms on the opposite side were included in this clinical study as group II (a 40-year-old man and 4 women [mean age 40 years, range 17-54 years).

Prior to surgical intervention, in both groups conservative therapy methods were attempted, such as bed rest, anti-inflammatory and myorelaxant medication, and physical treatment, for at least one month, and patients who did not show satisfactory improvement underwent surgery. Hemi partial laminectomies and simple discectomies were performed in both groups. The second group was operated on only from the disc herniated side in the same manner as group I without any intervention on the opposite side.

\section{Morphometric analysis}

Lumbosacral magnetic resonance imaging (MRI) was performed in both groups. All subjects were admitted to the Departments of Neurosurgery in Kocatepe, Adnan Menderes and Yeditepe Universities, Faculty of Medicine and Spine Centre in Istanbul. Informed consent of the patients in both study and control groups was obtained. Consecutive $0.2 \mathrm{~cm}$ thick serial 1.5 Tesla MRI (Philips Systems, Netherlands) from axial T1 weighted with SE T1A (TR 500-700 ms, TE 10-30 ms) was selected to measure disc spaces, spinal canal diameters and ligamentum flavum with a millimetric caliper. On the T1-weighted axial images through the facet 
joint, the thickness at the middle portion of the ligamentum flavum of all these patients was measured bilaterally at the level of disc herniation (Figure 2), as described in a previous study [6]. All measurements were performed blinded to subject details, and were done three times in each trial by an anatomist and blinded neurosurgeon independently. The mean of these measurements was accepted for use in statistics.

\section{Statistical analysis}

Age, sex, spinal canal diameters and thickness of the ligamentum flavum and disc spaces for all levels were evaluated for both groups using the Shapiro-Wilk test. The groups did not show a normal distribution so we used non-parametric tests for statistical evaluation. We used the KruskalWallis test for multiple comparison of more than two independent groups and after that the Dunn test was used. We used the Wilcoxon test for comparison of two dependent groups. We compared statistically these groups for any significant differences in thicknesses of the ligamenta flava ipsilaterally and contralaterally, and spinal canal diameters depending on age and gender. We also compared bilateral ligament thickness of each group for themselves. But we did not have a sufficient sample size for group II, so we could not compare between group I and group II. The levels of significance were indicated by $p$ values, and all $p$ values less than 0.05 were considered to indicate statistical significance. The statistical analyses were performed by using the software package SPSS (SPSS version 16.0; SPSS Inc., Chicago, IL, USA) for Windows.

\section{Results}

In group I, the mean thickness of the ligamenta flava was $2.27 \pm 0.39 \mathrm{~mm}$ ipsilaterally and 2.23 $\pm 0.39 \mathrm{~mm}$ contralaterally. In group II, the mean thickness of the ligamenta flava was $3.28 \pm 1.65 \mathrm{~mm}$ on the same side of disc herniation and 4.6 $\pm 1.94 \mathrm{~mm}$ on the opposite side of disc herniation. Diameters of the spinal canals of the cases were $11.02 \pm 0.78 \mathrm{~mm}$ in group I and $10.83 \pm 0.65 \mathrm{~mm}$ in group II.

Further examination by electromyography was performed for 5 patients with contralateral side symptoms to support the diagnosis of radicular compression. These patients were operated on only from the side of disc herniation. Preoperative and postoperative evaluations of patients were performed using the Oswestry Disability Index (ODI) [7]. The clinical findings of group II are summarized in Table I.

Distribution of cases and results of means \pm SD (standard deviation) according to age, sex, ligament

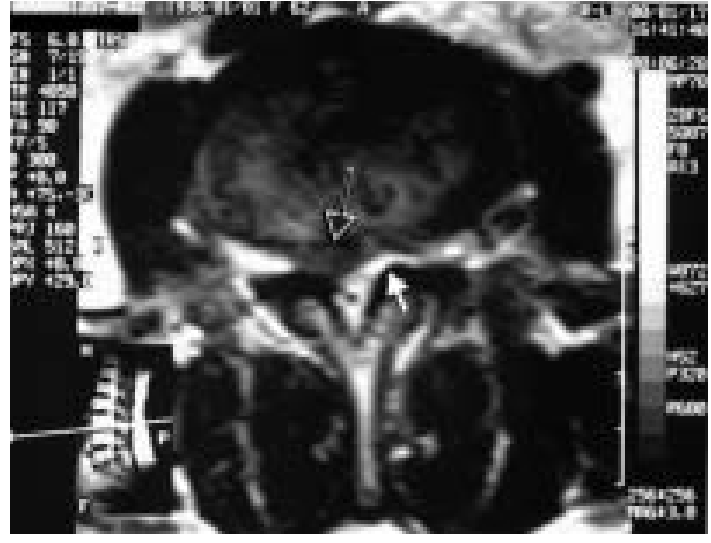

Figure 2. On the right side herniated disc (black arrow) and contralateral hypertrophic ligamentum flavum (white arrow) are shown on the T1-weighted axial MRI image

thickness and levels of disc herniation in each group is shown in Tables II, III. We found statistically significant differences for total thickness of the ligamentum flavum in group I in females (see Table II). We also found statistically significant differences in males except for L3-L4 and L5-S1 thicknesses (see Table III). The thickness of the ligamentum flavum in group II was thicker than in group I. We had a small sample size in group II. For this reason we could not apply statistical evaluation for group II.

In group I, statistically significant differences were found for thickness of the ipsilateral ligamenta flava $(p<0.001)$ and also contralateral ligamenta flava $(p<0.001)$ depending on gender. There was no statistically significant difference between males and females depending on age $(p=0.163)$. We compared thickness of the ligamentum flavum for each level of disc herniation, and ligamentum flavum hypertrophy was more common at L3-L4 and L4-L5 levels of vertebrae in females. There was no statistically significant difference between the data of the spinal canal diameters of the groups.

\section{Discussion}

Mechanical deformation of the nerve roots and biochemical activity of the disc tissue affect the roots and result in sciatica or leg pain $[8,9]$. Nucleus pulposus also has an effect on reduction of blood flow at the dorsal roots as a secondary mechanism of sciatica [10]. But all these developing symptoms are related to contact disc protrusion to the nerve root.

There are a few reports about lumbar disc herniation with contralateral symptoms in the literature and all of them are presented as a case study or case series like our study. Our 5 patients in group II demonstrated painful radiculopathy on the opposite side of the disc herniation and there 
Table I. Clinical findings of group II

\begin{tabular}{|c|c|c|c|c|c|c|}
\hline $\begin{array}{l}\text { Age } \\
\text { and sex }\end{array}$ & $\begin{array}{l}\text { Symptoms } \\
\text { and sign. }\end{array}$ & $\begin{array}{l}\text { Diagnostic } \\
\text { procedure finding }\end{array}$ & Operation & $\begin{array}{l}\text { Follow-up } \\
\text { period }\end{array}$ & $\begin{array}{l}\text { Pre-op. } \\
\text { ODI (\%) }\end{array}$ & $\begin{array}{l}\text { Post-op. } \\
\text { ODI (\%) }\end{array}$ \\
\hline $17, \mathrm{~F}$ & $\begin{array}{l}\text { LBP and left sciatica } \\
\text { for } 2 \text { years } \\
\text { Bilaterally SLR } \\
\text { test }(+) \text {, left } \\
\text { hypoestesia of } \\
\text { L5 dermatoma }\end{array}$ & $\begin{array}{l}\text { MRI: right L4-L5 } \\
\text { HNP } \\
\text { EMG: left L5 } \\
\text { radicular } \\
\text { compression }\end{array}$ & $\begin{array}{l}\text { Right L4 } \\
\text { hemipartial } \\
\text { laminectomy } \\
\text { and L4-L5 } \\
\text { discectomy }\end{array}$ & 34 months & 56 & 18 \\
\hline $40, M$ & $\begin{array}{l}\text { LBP for } 3 \text { years, } \\
\text { left sciatica } \\
\text { for last } 9 \text { months, } \\
\text { left SLR (+), } \\
\text { hypoestesia of left } \\
\text { L5 and S1 dermatomas }\end{array}$ & $\begin{array}{l}\text { MRI: right L4-L5 } \\
\text { HNP } \\
\text { EMG: left L5 } \\
\text { radicular } \\
\text { compression } \\
\end{array}$ & $\begin{array}{l}\text { Right L4 } \\
\text { hemipartial } \\
\text { laminectomy } \\
\text { and L4-L5 } \\
\text { discectomy }\end{array}$ & 9 years & 68 & 12 \\
\hline $45, F$ & $\begin{array}{l}\text { LBP for } 5 \text { years, } \\
\text { left sciatica } \\
\text { for } 2 \text { years, } \\
\text { bilaterally SLR (+), } \\
\text { hypoestesia of left } \\
\text { S1 dermatoma }\end{array}$ & $\begin{array}{l}\text { MRI: right L5-S1 } \\
\text { HNP } \\
\text { EMG: left S1 } \\
\text { radicular } \\
\text { compression }\end{array}$ & $\begin{array}{l}\text { Right L5 } \\
\text { hemipartial } \\
\text { laminectomy } \\
\text { and L5-S1 } \\
\text { discectomy }\end{array}$ & 37 months & 44 & 20 \\
\hline $44, F$ & $\begin{array}{l}\text { LBP for } 4 \text { years } \\
\text { and left sciatica for } \\
3 \text { years, left SLR (+) } \\
\text { hypoestesia of left } \\
\text { L5 dermatoma }\end{array}$ & $\begin{array}{l}\text { MRI: right L4-L5 } \\
\text { HNP, L5-S1 } \\
\text { central HNP } \\
\text { EMG: L5 radicular } \\
\text { compression }\end{array}$ & $\begin{array}{l}\text { Right L4 and L5 } \\
\text { hemipartial } \\
\text { laminectomies, } \\
\text { L4-L5 and L5-S1 } \\
\text { discectomies }\end{array}$ & 6 years & 76 & 24 \\
\hline $54, \mathrm{~F}$ & $\begin{array}{l}\text { LBP and left sciatica } \\
\text { for } 1 \text { year, } \\
\text { left SLR (+) }\end{array}$ & $\begin{array}{l}\text { MRI: right L3-L4 } \\
\text { HNP } \\
\text { EMG: left L4 } \\
\text { radicular } \\
\text { compression }\end{array}$ & $\begin{array}{l}\text { Right L3 } \\
\text { hemipartial } \\
\text { laminectomy } \\
\text { and L3-L4 } \\
\text { discectomy }\end{array}$ & 5 years & 48 & 16 \\
\hline
\end{tabular}

Table II. Results of the ligament flava thickness of female subjects in group 1 are shown according to levels of disc herniation and pain symptomatology

\begin{tabular}{|c|c|c|c|c|}
\hline Disc levels & $\begin{array}{c}\text { L3-L4 } \\
\text { Mean } \pm \text { SD } \\
\text { (median) }\end{array}$ & $\begin{array}{l}\text { L4-L5 } \\
\text { Mean } \pm \text { SD } \\
\text { (median) }\end{array}$ & $\begin{array}{c}\text { L5-S1 } \\
\text { Mean } \pm \text { SD } \\
\text { (median) }\end{array}$ & $\begin{array}{c}\text { Value of } \\
p\end{array}$ \\
\hline $\begin{array}{l}\text { Thickness of } \\
\text { ipsilateral ligament } \\
\text { flava }[\mathrm{cm}]\end{array}$ & $\begin{array}{c}2.32 \pm 0.38 \\
(2.30)\end{array}$ & $\begin{array}{c}2.40 \pm 0.39 \\
(2.40)\end{array}$ & $\begin{array}{c}2.04 \pm 0.34 \\
(2.0)\end{array}$ & $<0.01^{*}$ \\
\hline $\begin{array}{l}\text { Thickness of } \\
\text { contralateral ligament } \\
\text { flava }[\mathrm{cm}]\end{array}$ & $\begin{array}{c}2.30 \pm 0.38 \\
(2.30)\end{array}$ & $\begin{array}{c}2.36 \pm 0.39 \\
(2.30)\end{array}$ & $\begin{array}{c}1.98 \pm 0.33 \\
(1.95)\end{array}$ & $<0.001^{\star}$ \\
\hline Value of $p$ & $<0.05^{\star}$ & $<0.001^{*}$ & $<0.05^{\star}$ & \\
\hline
\end{tabular}

Table III. Results of the ligament flava thicknesses of male subjects in group 1 are shown according to levels of disc herniation and pain symptomatology

\begin{tabular}{|c|c|c|c|c|}
\hline Disc levels & $\begin{array}{l}\mathrm{L} 3-\mathrm{L} 4 \\
\text { Mean } \pm \mathrm{SD} \\
\text { (median) }\end{array}$ & $\begin{array}{l}\text { L4-L5 } \\
\text { Mean } \pm \text { SD } \\
\text { (median) }\end{array}$ & $\begin{array}{c}\text { L5-S1 } \\
\text { Mean } \pm \text { SD } \\
\text { (median) }\end{array}$ & $\begin{array}{c}\text { Value of } \\
p\end{array}$ \\
\hline $\begin{array}{l}\text { Thickness of } \\
\text { ipsilateral ligament } \\
\text { flava }[\mathrm{cm}]\end{array}$ & $\begin{array}{c}2.08 \pm 0.22 \\
(2.10)\end{array}$ & $\begin{array}{c}2.20 \pm 0.38 \\
(2.15)\end{array}$ & $\begin{array}{c}1.90 \pm 0.32 \\
(1.90)\end{array}$ & $<0.01^{*}$ \\
\hline $\begin{array}{l}\text { Thickness of } \\
\text { contralateral ligament } \\
\text { flava }[\mathrm{cm}]\end{array}$ & $\begin{array}{c}2.08 \pm 0.22 \\
(2.10)\end{array}$ & $\begin{array}{c}2.16 \pm 0.39 \\
(2.10)\end{array}$ & $\begin{array}{c}1.89 \pm 0.24 \\
(1.90)\end{array}$ & $<0.05^{*}$ \\
\hline Value of $p$ & $>0.05$ & $<0.001^{*}$ & $>0.05$ & \\
\hline
\end{tabular}


was no evidence to contact the roots with disc materials on MRI. In the literature, atypical disc herniation with contralateral symptoms was reported and migration of disc herniation to the opposite side was observed on MRI [10, 11]. Sucu and Gelal reported 5 case series similar to our study and proposed that the contralateral symptoms may be related to traction of opposite side roots [12]. Their descriptive study suggested that surgical intervention only to the disc side was sufficient. In our study, we examined the thickness of the ligamentum flavum at the level of disc herniation bilaterally and found that total thickness of the ligamentum flavum of group II was greater than that of group I. When we separately compared the thickness of the ligamentum flavum ipsilaterally and contralaterally for each group, it was found that opposite side thickness of the ligamentum flavum in group II was greater than that of group I contralaterally and ipsilaterally, but not ipsilaterally within group II. These results were explicated that group II had hypertrophied and asymmetrical ligamenta flava. When we obtained the data on unilateral thickness of the ligamentum flava we thought that probably these ligaments were thick as a variation because mechanical of degenerative disease may affect both sides of the ligament.

We thought that the asymmetrical ligamenta flava hypertrophy could contribute to foraminal stenosis of the opposite side and displacement of the dura to the opposite side due to disc herniation resulting in compression of the contralateral root. According to this mechanism, we also performed surgery at the side of disc herniation and these patients' outcomes were sufficient for recovery of sciatica.

Of course it seems to be a challenge to decide on an operation only from the disc herniated side without any controlling opposite side but some knowledge of the literature has helped us to restrict the operation to only the disc herniated side. Hypertrophied ligamentum flavum is considered to be one of the important causes of spinal stenosis in lumbar degenerative disease. Aging and degeneration of the ligamentum flavum cause increasing thickness and bulging of ligaments, but the aging process of the spine is not easy to distinguish from degenerative change in spinal stenosis [13]. The histology of the ligamentum flavum in spinal stenosis reveals an increase in calcification and collagen fibre and a decrease in elastic fibres [14]. Fibrosis is the main cause of ligamentum flavum hypertrophy and is induced by mechanical stress which increases with the aging process [15]. There are a lot of reports about hypertrophied ligamentum flavum and its contribution to spinal stenosis and radiculopathy, but no reports about compression of roots resulting in radiculopathy of pure hypertrophied ligament without ossification, haematoma, pseudo-cystic or myxomatous degeneration of the ligamentum flavum [16-22].

As segmental lumbar instability poses diagnostic problems due to the lack of clear radiological and clinical criteria, only little is known about the occurrence of this phenomenon following primary microdiscectomy [23]. Because ossifications or other pathological lesions of the ligamentum flavum have not been seen in MRI, we think that hypertrophied ligamentum flavum is a contributory factor and is not the primary pathology. The mechanism of contralateral side symptomatology seems to be as in Kernohan's notch syndrome, in which an uncal herniation causes displacement of the cerebral peduncle against the edge of the tentorial notch, resulting in a false localizing sign [5]. As in this mechanism, we have suggested that the ipsilateral nerve root and dural sac may be displaced posteriorly and laterally towards the contralateral foramina without significant compression but the opposite side nerve root is compressed between the facet and hypertrophied ligamenta flava in the lateral recess. Nakagawa et al. reported two disc herniation cases with contralateral symptoms and their endoscopic surgical observation revealed inflammatory findings of the nerve root on the symptomatic side, such as fibrosis, adhesion and swelling, but the ipsilateral asymptomatic disc herniated side did not demonstrate any findings of inflammation or compression [24]. We thought that these observations might be secondary to displacement of the dura and compression of the contralateral nerve root.

In conclusion, our results indicate that sciatica with contralateral disc herniation may be related to hypertrophied and asymmetrical ligamenta flava, but more evidence from more patients must be provided to support this theory. Although only disc sided operations' outcomes were sufficient, other pathology of the contralateral side must be evaluated carefully in each case. These data could also provide clear morphometric information, guidance, clinical contribution and safe while planning and during lumbar discectomy operations.

\section{Acknowledgments}

We would like to thank Mr. Bedri Karatas for his assistance with the grammar of the manuscript.

\section{References}

1. Williams PL, Bannister LH, Berry MM. Back and macroscopic anatomy of spinal cord. In: Williams A, Newell RL, Collins P (eds). Gray's anatomy. Ed. 38. London: Churchill-Livingstone 1995; 769-70. 
2. Moore KL, Dalley AF. Back. In: Moore KL, Dalley AF (eds). Anatomy, clinically oriented. Ed 4. Philadelphia: Lippincott Williams and Wilkins 1999; 450-7.

3. Kawakami M, Tamaki T, Hayashi N, Hashizume H, Nishi H. Possible mechanism of painful radiculopathy in lumbar disc herniation. Clin Orthop Relat Res 1998; 351: 241-51.

4. Jhawar B S, Mitsis D, Duggal N. Wrong-sided and wronglevel neurosurgery: a national survey. J Neurosurg Spine 2007; 7: 467-72.

5. Pearce JM. Kernohan's notch. Eur Neurol 2006; 55: 230-2.

6. Schulte TL, Heidenreich JO, Schilling AM, et al. Comparision of metric analysis of spinal structures, exemplarily of the ligamentum flavum, obtained with CT and MRI. Eur J Radiology 2004; 52: 224-8.

7. Fairbank JC, Pynsent PB. The Oswestry Disability Index. Spine (Phila Pa 1976) 2000; 25: 2940-53.

8. Omarker K, Myers RR. Pathogenesis of sciatic pain: role of herniated nucleus pulposus and deformation of spinal nevre root and dorsal root ganglion. Pain 1998; 78 : 99-105.

9. Kobayashi S, Baba H, Uchida K, et al. Effect of mechanical compression on the lumbar nerve root: localization and changes of intraradicular inflamatory cytokines, nitric oxide and cyclooxygenase. Spine (Phila Pa 1976) 2005; 30: 1699-705.

10. Yabuki S, Igarashi T, Kikuchi S. Application of nucleus pulposus to the nerve root simultaneously reduces blood flow in dorsal root ganglion and corresponding hindpaw in the rat. Spine (Phila Pa 1976) 2000; 25: 1471-6.

11. Branam BR, Stambough JL. Atypical lumbar disc herniation: a case report. Spine J 2002 2: 224-6.

12. Sucu HS, Gelal F. Lumbar disk herniation with contralateral symptoms. Eur Spine J 2006; 15: 570-4.

13. Benoist M. Natural history of aging spine. Eur Spine J 2003; 12 (Suppl 2): 86-9.

14. Schräder PK, Grob D, Rahn BA, Cordey J, Dvorak J. Histology of the ligamentum flavum in patients with degenerative lumbar spinal stenosis. Eur Spine J 1999; 8: 323-8.

15. Sairyo K, Biyani A, Goel V, et al. Pathomechanism of ligamentum flavum hypertrophy: a multidisciplinary investigation based on clinical, biomechanical, histologic and biologic assessments. Spine (Phila Pa 1976) 2005; 30: 2649-56.

16. Hirakawa K, Hanakita J, Suwa $\mathrm{H}$, et al. A post-traumatic ligamentum flavum progressive hematoma: a case report. Spine (Phila Pa 1976) 2000; 25: 1182-4.

17. Keynan O, Smorgick Y, Schwartz AJ, Ashkenazi E, Floman Y. Spontaneous ligamentum flavum hematoma in the lumbar spine. Skeletal Radiol 2006; 35: 687-9.

18. Kotil K, Bilge T. A ligamentum flavum hematoma presenting as an L5 radiculopathy. J Clin Neurosc 2007; 14: 994-7.

19. Mizuno J, Nakagawa $H$, Inoue T, Hashizume $Y$. Ligamentum flavum hematoma in the lumbar spine. Neurol Med Chir (Tokyo) 2005; 45: 212-5.

20. Minamide A, Yoshida M, Tamaki T, Natsumi K. Ligamentum flavum hematoma in the lumbar spine. J Orthop Sci 1999; 4: 376-9.

21. Pascal-Mousselard H, Smadja D, Cabre P, Raynaud M, Catonne Y. Ossification of the ligamentum flava with severe myelopathy in a black patient: a case report. Spine (Phila Pa 1976) 1998; 23: 1607-8.

22. Yoshii S, Ikeda K, Murakami H. Myxomatous degeneration of the ligamentum flavum of the lumbar spine. Spinal Cord 2001; 39: 488-91.
23. Schaller B. Failed back surgery syndrome: the role of symptomatic segmental single-level instability after lumbar microdiscectomy. Eur Spine J 2004; 13: 193-8.

24. Nakagawa Y, Yoshida M, Kawakami M, et al. Posterior endoscopic surgery for lumbar disc herniation with contralateral symptoms - a report of two cases. Minim Invasive Neurosurg 2006; 49: 282-5. 